\title{
Effect of duration of night interruption on growth and flowering of Chrysanthemum cv. Kikiobiory
}

\author{
Tanya Thakur* and H.S. Grewal \\ Department of Floriculture and Landscaping, Punjab Agricultural University, Ludhiana - 141001 (Punjab), INDIA \\ *Corresponding author. E-mail: tanyathakurflori@gmail.com
}

Received: October 7, 2015; Revised received: February 25, 2016; Accepted: May 28, 2016

\begin{abstract}
The study was conducted to determine the effect of duration of night interruption using incandescent bulbs on sustained quality flower production of potted standard Chrysanthemum cv. Kikiobiory. The different night interruption ( $\mathrm{NI})$ treatments i.e. control, $<5 \mathrm{sec}$. flash, 30-, 60-, 90- and 120- min. significantly $(p<0.05)$ affected all the vegetative and floral parameters. The plant height, number of leaves and root suckers per plant increased with the increase duration of $\mathrm{NI}$ treatments with maximum at $120-\min$. NI $(90.42 \mathrm{~cm}, 34.75$ and 12.10 , respectively). The days taken to flower bud appearance, colour break stage and full bloom were delayed, whereas flower quality with respect to duration of flowering and flower diameter were deteriorated with increase in duration of NI treatments. The days taken to flower bud appearance, colour break stage and full bloom were highest at 120- $\min$. NI (136.84, 183.22 and 202.25 days, respectively) which delayed the flowering by 63.94 days, where full bloom flower appeared in March. There was reduction in duration of flowering and flower diameter with increased $\mathrm{NI}$ duration with lowest at $120 \mathrm{~min}$. NI (7.83 days and $15.69 \mathrm{~cm})$. It was observed that increase $(120 \mathrm{~min}$.) in night interruption increased the vegetative growth and delayed the flowering; however, flower quality was deteriorated. Thus, it was concluded that $60 \mathrm{~min}$. NI improved flower quality with sustained flower production in potted Chrysanthemum cv. Kikiobiory.
\end{abstract}

Keywords: Chrysanthemum, Incandescent bulbs, Kikiobiory, Night Interruption, Vegetative Growth

\section{NTRODUCTION}

Photoperiod, day light exposure of plants, regulates morphological development in many floriculture crops like Poinsettia, Kalanchoe etc. and commercial growers provide long days through artificial lighting to maintain vegetative growth for cutting production in chrysanthemum (Dole and Wilkins, 2005) and to regulate flowering of photoperiod-sensitive species (Blanchard and Runkle, 2009; Chen et al., 2010; Mattson and Erwin, 2005; Yamada et al., 2008). In the open cultivation, the flowering of chrysanthemum is confined only to limited period from October to December thus, the monitoring of photoperiod provides growers with an efficient crop schedule according to demand of flowers in the market. Chrysanthemum is a photosensitive plant with critical day length of $131 / 2 \mathrm{~h}$ (Post, 1931; Furuta, 1954) and day length of $<13 \frac{1}{2} \mathrm{~h}$ promote flowering in chrysanthemum (Runkle and Fisher, 2004). The flowering could even be promoted by subjecting the plants to dark periods of more than $12 \mathrm{hr}$ or inhibited by the interruption of long-night called as night break with a short exposure to red light with continuous or intermittent low intensity light (cyclic light) using fluorescent or incandescent lamp (Cathey and Borthwick, 1964). Ochiai et al. (2015) reported that night-break (NB) treatment inhibited flowering in short-day plants and was widely used in the flower production of cut chrysanthemum (Chrysanthemum morifolium Ramat.). The flowISSN : 0974-9411 (Print), 2231-5209 (Online) All Rights Reserved (C) Applied and Natural Science Foundation www.jans.ansfoundation.org ering of chrysanthemum was inhibited by night interruption with red light $(660 \mathrm{~nm})$ but subsequently irradiated far-red light $(730 \mathrm{~nm})$ induced the flowering of chrysanthemum, this photoreversible flowering responses is regulated by the plant photoreceptor phytochrome B (Hong et al., 2013). It is therefore, always desirable to control short-day effect for controlling the vegetative growth or extend the flowering duration in chrysanthemum for off -season availability of flowers. The incandescent (INC) lamp has been widely used to deliver photoperiodic lighting in both greenhouses and growth chambers because of its efficacy and low purchase price (Bickford and Dunn, 1972). The flowering is uniform under photoperiod shorter than critical photoperiod, whereas, flowering is not uniform and the buds do not develop normally under longer photoperiods (Furuta, 1954). This study was aimed to investigate the effect of photoperiodic night interruption on growth and flowering of chrysanthemum.

\section{MATERIALS AND METHODS}

The experiment was conducted at Department of Floriculture and Landscaping, Punjab Agricultural University, Ludhiana during 2014-15. The terminal cuttings were taken from the mother stock plants pinched in end of May to encourage more number of axillary shoots of 
pot standard chrysanthemum cultivar Kikiobiory. The terminal cuttings $(5-7 \mathrm{~cm})$ were treated with IBA $400 \mathrm{mg} / 1$ (Indole butyric acid) and planted in burnt rice husk for rooting in June-July.

The rooted cuttings were then transplanted during end July in the pots ( 8 ') containing mixture of soil and FYM (2:1) along with diammonium phosphate (DAP) incorporated as a basal dose@1 kg/100 cubic feet. The plants were given night interruption (NI) treatments 30 days after planting (DAP) using incandescent bulbs (100 watt, $1.25 \mathrm{~m}$ above pot) for 2 months starting from $20^{\text {th }}$ September till $20^{\text {th }}$ November. The plants were kept under natural short day open conditions thereafter. The night interruption were given starting from 22:00 to 24:00 as per the treatments- (i) $\mathrm{T} 0=$ control, (ii) $\mathrm{T} 1=<5 \mathrm{sec}$ (flash of light), (iii) T2 = $30 \mathrm{~min}$, (iv) T3 = $60 \mathrm{~min}$, (v) T4 $=90 \mathrm{~min}$ and (vi) $\mathrm{T} 5=120 \mathrm{~min}$. The experiment was conducted in the Completely Randomized Design by replicating the treatment thrice. The effect of different durations of night interruption on vegetative growth (at 15 days interval) and floral parameters were recorded and statistical analysis was performed using SAS software and treatment means were compared using Duncan Multiple Range Test (DMRT) at 5\% level of significance (Duncan, 1955).

\section{RESULTS AND DISCUSSION}

Vegetative growth: In the present study, photoperiodic treatments significantly $(\mathrm{p}<0.05)$ influenced the plant height, number of leaves 15, 30 and 45 days after night interruption (NI) and root suckers per plant in Chrysanthemum cv. Kikiobiory (Table 1). The plant height after 15 days of NI in all photoperiodic treat- ments was better than the control $(24.71 \mathrm{~cm})$, but was at par among them. The plant height after 30 days of NI increased significantly $(\mathrm{p}<0.05)$ with $60-, 90$ - and $120-\mathrm{min}$. NI $(54.38,58.59$ and $61.52 \mathrm{~cm}$, respectively), whereas, other treatments were at par among them. The plant height after 45 days of NI (Fig 1) in all treatments was significantly $(\mathrm{p}<0.05)$ better than the control $(63.17 \mathrm{~cm})$ with maximum in $120 \mathrm{~min}$. NI $(90.42 \mathrm{~cm})$. The number of leaves per plant after 15 days of NI were significantly $(\mathrm{p}<0.05)$ better in 120 min. NI (19.62) than other treatments viz. control (14.11), <5 sec. flash (14.99) and $30 \mathrm{~min}$. (15.17) NI, and were at par among them. The number of leaves per plant after 30 days of NI were better in 120- and 90min. NI (28.39 and 26.95) but at par among them. The number of leaves per plant after 45 days of NI (Fig 2) increased significantly $(\mathrm{p}<0.05)$ with $30-, 60-, 90-$ and 120 - min. NI $(27.06,29.09,31.58$ and 34.75, respectively) whereas, control (24.70) and $<5 \mathrm{sec}$. flash NI (24.31) were at par among them. The number of root suckers per plant were significantly $(\mathrm{p}<0.05)$ better in 90- and 120- min. NI (11.20 and 12.10) but were at par among them. There was significant $(\mathrm{p}<0.05)$ increase in number of root suckers in the control $(8.85),<5 \mathrm{sec}$. flash (9.43), 30- (10.94) and 60- (10.47) min. NI treatment. For commercial production of cut stems, the chrysanthemum plants are to be maintained in vegetative state for rapid growth and to attain the desired stem length before flower induction, as long stem fetch good market price (Datta and Ramadas, 2000; Datta and Gupta, 2012). In chrysanthemum, long day conditions and proper night temperature promoted vegetative growth in varieties grown for year around flower-

Table 1. Vegetative growth of Chrysanthemum cv. Kikiobiory under different night interruption treatments.

\begin{tabular}{|c|c|c|c|c|c|c|c|c|c|}
\hline \multirow[b]{2}{*}{$\begin{array}{l}\text { Treatments } \\
\text { (duration } \\
\text { of NI) }\end{array}$} & \multicolumn{4}{|c|}{ Plant height (cm) } & \multicolumn{4}{|c|}{ Number of leaves/plant } & \multirow[b]{2}{*}{$\begin{array}{l}\text { Number of } \\
\text { root suck- } \\
\text { ers/ plant }\end{array}$} \\
\hline & $\begin{array}{l}\text { Start- } \\
\text { ing of } \\
\text { NI }\end{array}$ & $\begin{array}{l}15 \text { days } \\
\text { after } \mathrm{NI}\end{array}$ & $\begin{array}{l}30 \text { days } \\
\text { after NI }\end{array}$ & $\begin{array}{l}45 \text { days } \\
\text { after } \\
\text { NI }\end{array}$ & $\begin{array}{l}\text { Start- } \\
\text { ing of } \\
\text { NI }\end{array}$ & $\begin{array}{l}15 \text { days } \\
\text { after } \mathrm{NI}\end{array}$ & $\begin{array}{l}30 \text { days } \\
\text { after NI }\end{array}$ & $\begin{array}{l}45 \text { days } \\
\text { after } \mathrm{NI}\end{array}$ & \\
\hline Control & $14.04 \mathrm{a}$ & $24.71 \mathrm{~b}$ & $49.95 \mathrm{c}$ & $63.17 \mathrm{~d}$ & $9.52 \mathrm{a}$ & $14.11 \mathrm{c}$ & $20.72 \mathrm{c}$ & $24.70 \mathrm{e}$ & $8.85 \mathrm{c}$ \\
\hline$<5 \mathrm{sec}$ & $14.11 \mathrm{a}$ & $27.47 \mathrm{a}$ & $50.71 \mathrm{c}$ & $70.86 \mathrm{c}$ & $9.90 \mathrm{a}$ & $14.99 \mathrm{c}$ & $20.41 \mathrm{c}$ & $24.31 \mathrm{e}$ & $9.43 \mathrm{bc}$ \\
\hline $30 \mathrm{~min}$. & $14.93 \mathrm{a}$ & $28.00 \mathrm{a}$ & $50.61 \mathrm{c}$ & $71.44 \mathrm{c}$ & $9.41 \mathrm{a}$ & $15.17 \mathrm{c}$ & $21.27 \mathrm{bc}$ & $27.06 \mathrm{~d}$ & $10.94 \mathrm{ab}$ \\
\hline $60 \mathrm{~min}$. & $14.45 \mathrm{a}$ & $28.66 \mathrm{a}$ & $54.38 \mathrm{bc}$ & $80.13 b$ & $10.62 \mathrm{a}$ & $17.72 \mathrm{~b}$ & $23.51 \mathrm{~b}$ & $29.09 \mathrm{c}$ & $10.47 \mathrm{abc}$ \\
\hline $90 \mathrm{~min}$. & $15.04 \mathrm{a}$ & $29.23 \mathrm{a}$ & $58.59 \mathrm{ab}$ & $84.20 \mathrm{~b}$ & $9.53 \mathrm{a}$ & $17.44 \mathrm{~b}$ & $26.95 \mathrm{a}$ & $31.58 \mathrm{~b}$ & $11.20 \mathrm{a}$ \\
\hline $120 \mathrm{~min}$. & $14.88 \mathrm{a}$ & $\begin{array}{l}29.42 \mathrm{a} \\
*\end{array}$ & $\begin{array}{l}61.52 \mathrm{a} \\
*\end{array}$ & $\begin{array}{l}90.42 \mathrm{a} \\
*\end{array}$ & $10.47 \mathrm{a}$ & $\begin{array}{l}19.62 \mathrm{a} \\
*\end{array}$ & $\begin{array}{l}28.39 \mathrm{a} \\
*\end{array}$ & $\begin{array}{l}34.75 \mathrm{a} \\
*\end{array}$ & $\begin{array}{l}12.10 \mathrm{a} \\
*\end{array}$ \\
\hline
\end{tabular}

Table 2. Time of flowering and flower quality of Chrysanthemum cv. Kikiobiory under different night interruption treatments

\begin{tabular}{llllll}
\hline Treatments & $\begin{array}{l}\text { Days to flower bud } \\
\text { appearance }\end{array}$ & $\begin{array}{l}\text { Days to color } \\
\text { break stage }\end{array}$ & $\begin{array}{l}\text { Days to full } \\
\text { bloom }\end{array}$ & $\begin{array}{l}\text { Duration of } \\
\text { flowering (days) }\end{array}$ \\
\hline Control & $84.50 \mathrm{~d}$ & $111.69 \mathrm{e}$ & $138.31 \mathrm{e}$ & $10.00 \mathrm{~b}$ & $\begin{array}{l}\text { Flower diameter } \\
\text { (cm) }\end{array}$ \\
$<5 \mathrm{sec}$. NI & $98.60 \mathrm{c}$ & $128.85 \mathrm{~d}$ & $162.18 \mathrm{~d}$ & $9.69 \mathrm{bc}$ & $16.29 \mathrm{ab}$ \\
$30 \mathrm{~min} . \mathrm{NI}$ & $120.41 \mathrm{~b}$ & $154.46 \mathrm{c}$ & $178.01 \mathrm{c}$ & $10.45 \mathrm{~b}$ & $17.70 \mathrm{a}$ \\
$60 \mathrm{~min} . \mathrm{NI}$ & $122.82 \mathrm{~b}$ & $165.03 \mathrm{bc}$ & $192.24 \mathrm{~b}$ & $11.87 \mathrm{a}$ & $17.21 \mathrm{ab}$ \\
$90 \mathrm{~min} . \mathrm{NI}$ & $123.66 \mathrm{~b}$ & $171.06 \mathrm{~b}$ & $199.30 \mathrm{a}$ & $8.44 \mathrm{~cd}$ & $16.58 \mathrm{ab}$ \\
$120 \mathrm{~min}$ NI & $136.84 \mathrm{a}$ & $183.22 \mathrm{a}$ & $202.25 \mathrm{a}$ & $7.83 \mathrm{~d}$ & $16.70 \mathrm{ab}$ \\
F- test & $*$ & $*$ & $*$ & $*$ & $*$ \\
\hline
\end{tabular}

Mean values in each column with the same letter are not significantly different at $\mathrm{p}<0.05$ according to DMRT. ns $=$ non significant *Significant at $\mathrm{p}<0.05$. 


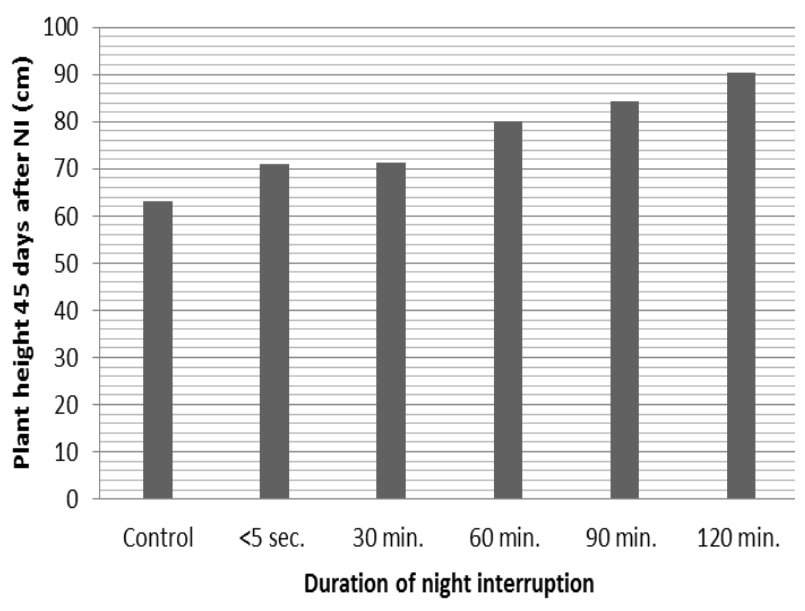

Fig. 1. Effect of night interruption on plant height $(\mathrm{cm})$ of Chrysanthemum cv. Kikiobiory.

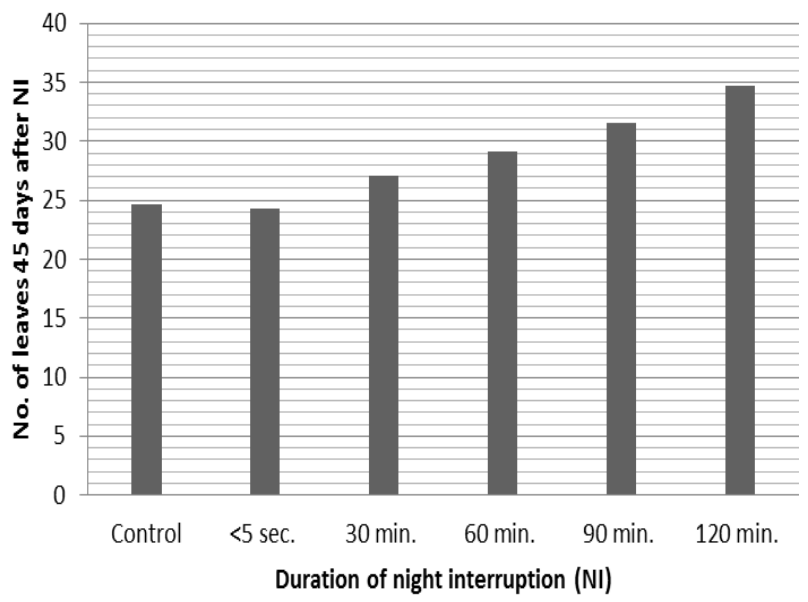

Fig. 2. Effect of night interruption on number of leaves per plant of Chrysanthemum cv. Kikiobiory.

ing (Datta, 2006). For vegetative state, chrysanthemum plants are maintained at day length of greater than $14.5 \mathrm{~h}$ while for flower bud development at day length less than $13.5 \mathrm{~h}$ (Furuta, 2004). In the present study, increased plant height, number of leaves and root suckers per plant in chrysanthemum under different photoperiodic night interruption were significantly $(p<0.05)$ higher than natural day length conditions. The exposure of plants to long day treatment during the critical phase would have probably caused a shift in balance of hormones leading to increase in gibberellins like substances that would have resulted in significant $(p<0.05)$ vegetative growth. The increased plant height and growth rate in chrysanthemum resulted from enhanced photosynthetic activity under artificial long day conditions accompanied by accumulation of carbohydrate and nitrogen (Datta and Ramadas, 2000). Similar results have been reported earlier in chrysanthemum (Hayashi et al., 2001; Jaime and Silva, 2003; Karlovic et al., 2004 and Kahar, 2008). Kurilcik et al. (2008) reported that the shoot length and number of

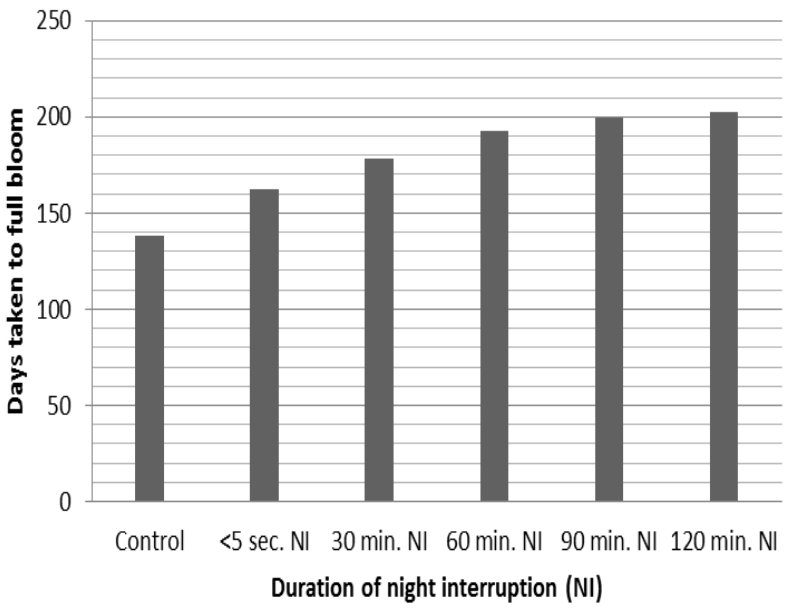

Fig. 3. Effect of night interruption on days to full bloom of Chrysanthemum cv. Kikiobiory.

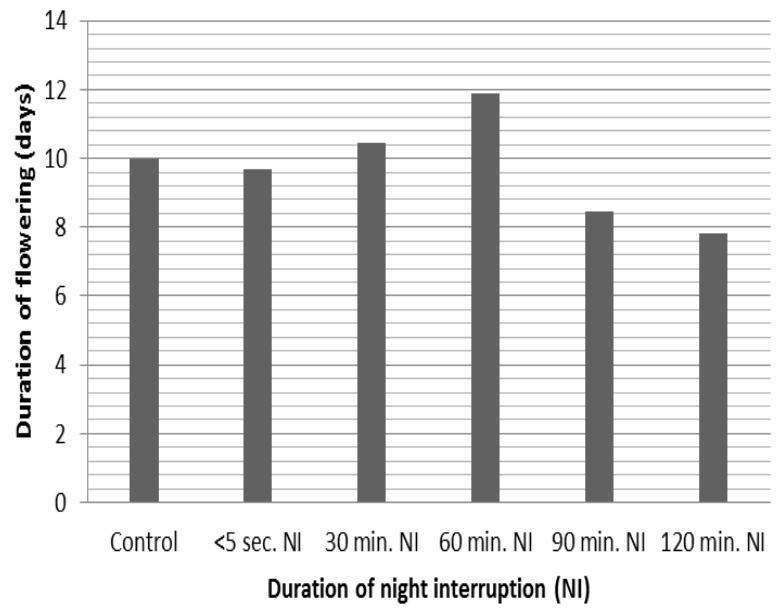

Fig. 4. Effect of night interruption on duration of flowering (days) of Chrysanthemum cv. Kikiobiory.

leaf in chrysanthemum plants continually increased with the increase of the photoperiod from $8 \mathrm{~h}$ to $24 \mathrm{~h}$ using light-emitting diode (LED)-based illuminator.

Time of flowering: In the present study, effect of different photoperiodic treatments on the days taken to flower bud appearance, color break stage and full bloom were significant $(\mathrm{p}<0.05)$ in Chrysanthemum cv. Kikiobiory and are summarized in Table 2. The days taken to flower bud appearance from planting in Chrysanthemum cv. Kikiobiory were significantly $(\mathrm{p}<0.05)$ better in all photoperiodic treatments than control (84.50 days) and bud appeared around $2^{\text {nd }}$ week November. The maximum days to flower bud appearance were obtained in 120- min. NI (136.34 days) where bud appeared in $1^{\text {st }}$ week January and delayed the bud appearance by 51.84 days. In 30-, 60and 90- min. NI flower bud appeared around mid- December (120.41, 122.82 and 123.66 days, respectively) which were at par among them and delayed the flower bud appearance by $35.91,38.32$ and 39.16 days, respectively. The days taken to color break stage from 
planting in Chrysanthemum cv. Kikiobiory were significantly $(\mathrm{p}<0.05)$ better in all photoperiodic treatments than the control (111.69 days) and color break stage appeared in $2^{\text {nd }}$ week of December. There were significant $(\mathrm{p}<0.05)$ increase in days taken to color break stage with $<5$ sec. flash, 30-, 60-, 90- and 120min. NI (128.85, 154.46, 165.03, 171.06 and 183.22 days, respectively), which delayed the color break stage by $17.16,42.77,53.34,59.37$ and 71.53 days, respectively and showed colored bud from end- December to mid- February. The days taken to full bloom from planting in Chrysanthemum cv. Kikiobiory (Fig $3)$ were significantly $(p<0.05)$ increased in all photoperiodic treatments than the control (138.31 days) and full blooming occurred in $1^{\text {st }}$ week of January. In 90and 120- min. NI days taken to full bloom (199.30 and 202.25 days $)$ were significantly $(\mathrm{p}<0.05)$ better than the other treatments, which delayed blooming by 60.99 and 63.94 days and full bloom appeared in March. The days taken to full bloom were delayed significantly $(\mathrm{p}<0.05)$ with $<5 \mathrm{sec}$. flash, 30 - and 60 - min. NI by $23.87,39.70$ and 53.93 days, respectively in endJanuary - February. In the present study, there was delayed flowering in Chrysanthemum cv. Kikiobiory under all photoperiodic treatments than the control, which might be due to low prevailing temperature conditions during December-January $\left(12.3-11.3^{\circ} \mathrm{C}\right)$ which hindered the flower bud development. The plants kept under the natural day length (control) completed their short day requirement earlier for initiation and development of flower buds than different duration of photoperiodic treatments. Kazaz et al. (2010) reported that natural long day conditions delayed flowering by 42 days in Chrysanthemum morifolium as compared to short day conditions by using black polyethylene. Similar results were reported by Korkut (1990), Hanke (1996) and Kaur (2014) in chrysanthemum plants. Ochiai et al. (2015) reported that night break treatments at 630-, 660-, and a combination of 660- and $735-\mathrm{nm}$ LEDs inhibited floral differentiation in all cultivars, but combination of 660- and 735-nm LEDs had the most stabile inhibitory effect on floral differentiation among chrysanthemum cultivars. The similar effect has been reported for Chrysanthemum cv. Iwa no hakusen (Liao et al., 2014) and Arajin2 and Iwa no hakusen (Hakuzan and Nagayoshi, 2013) under a combination of 663- and 732-nm night break.

Flower quality: In the present study, the flower quality with respect to duration of flowering and flower diameter (Table 2 ) were significantly $(\mathrm{p}<0.05)$ deteriorated with increase in duration of NI, with minimum (7.83 days and $15.69 \mathrm{~cm}$ ) at $120 \mathrm{~min}$. NI (Fig 4). The flower diameter was significantly $(\mathrm{p}<0.05)$ better in $<5$ sec. flash NI $(17.70 \mathrm{~cm})$ as compared to the control $(16.29 \mathrm{~cm})$, whereas other treatments were at par among them. The duration of flowering in Chrysanthemum cv. Kikiobiory was significantly $(\mathrm{p}<0.05)$ better in $60 \mathrm{~min}$. NI (11.87 days) as compared to the control and $30 \mathrm{~min}$. NI (10.00 and 10.45 days) which were at par among them. In the present study, there was reduction in duration of flowering in Chrysanthemum cv. Kikiobiory at 90- and 120- min. NI than the other treatments due to delayed flowering under 90- and 120 - min. NI which coincided with increased temperature in March $\left(19.4^{\circ} \mathrm{C}\right)$. The high temperature increased the respiration rate, depleted the plant of its carbon sources having adverse effect on longevity of the petals in chrysanthemum (Korfranek and Halevy, 1972) and also exhibited decline in water uptake. The high temperature during end March also caused hardening of stem which decreased the ability of the stem to absorb water (Larson, 1992). The flower diameter was reduced at $120 \mathrm{~min}$. NI was mainly attributed to the decreased temperature $\left(11.5^{\circ} \mathrm{C}\right)$ during flower bud appearance in January which hindered the expansion of flower buds (Kaur, 2014). These results are in conformity with the findings of Kaur (2014) who reported similar reduction in duration of flowering and flower diameter with increased exposure of chrysanthemum plants to night interruption.

\section{Conclusion}

The present study concluded that all vegetative parameters like plant height and number of leaves after 15, 30 and 45 days of night interruption (NI) and root suckers per plant in Chrysanthemum cv. Kikiobiory increased with the increase in duration of NI treatments, with maximum at $120-\min$. NI $(90.42 \mathrm{~cm}$, 34.75 and 12.10 , respectively). The days taken to flower bud appearance, colour break stage and full bloom were significantly $(p<0.05)$ delayed with increase in duration of NI. The $120 \mathrm{~min}$. NI delayed the flower bud appearance by 51.84 days where bud appeared in $1^{\text {st }}$ week January. The days to full bloom were delayed by 60.99 and 63.94 days at 90- and 120min. NI where full bloom appeared in March, but the flower quality was deteriorated as there were significant $(p<0.05)$ reduction in duration of flowering and flower diameter with minimum at $120 \mathrm{~min}$. NI (7.83 days and $15.69 \mathrm{~cm}$ ). Therefore, it was observed that night interruption of $120 \mathrm{~min}$. increased the vegetative growth and delayed the flowering up to two months; however, deteriorated the flower quality. Thus, it was concluded that night interruption of $60 \mathrm{~min}$. using incandescent bulbs produced the sustained quality flower production in potted standard Chrysanthemum cv. Kikiobiory.

\section{REFERENCES}

Bickford, E.D. and Dunn, S. (1972). Lightening for Plant Growth. Kent State Univ, Press, Kent, OH, USA.

Blanchard, M.G. and Runkle, E.S. (2009). Use of a cyclic high-pressure sodium lamp to inhibit flowering of chrysanthemum and velvet sage. Sci. Horti., 122: 448-454.

Cathey, H.M. and Borthwick, H.A. (1964). Significance of dark reversion of phytochrome in flowering of Chrysanthemum morifolium. Bot. Gaz., 125: 232-236. 
Chen, C.L., Tsai, Y.J. and Sung, J.M. (2010). Photoperiod effect on flowering and seed setting of Hypericum perforatum. Exploring Agric., 46: 393-400.

Dole, J. and Wilkins, H. (2005). Floriculture Principles and Species. $2^{\text {nd }}$ ed. Prentice-Hall, Upper Saddle River, NJ, USA.

Datta, J.P. and Ramadas, S. (2000). Growth, development and flowering of chrysanthemum (Dendranthema grandiflora Tzelev.) as influenced by long-day exposures. Orissa J. Horti., 28 (1): 7-13.

Datta, S.K. (2006). Advances in Ornamental Horticulture (ed. S K Bhattacherjee). Pointer Publishers, Jaipur, pp 1 $-19$

Datta, S.K. and Gupta, V.K. (2012). Year round cultivation of garden chrysanthemum (Chrysanthemum morifolium Ramat.) through photoperiodic response. Sci. \& Culture, 78 (1-2): 71-77.

Duncan, D.B. (1955). Multiple range and multiple F tests. Biometrics. 11:1-42.

Furuta, T. (1954). Photoperiod and flowering of Chrysanthemum morifolium. Proceed. American Soc. Hort. Sci., 63: 457-461.

Furuta, T. (2004). Photoperiod and flowering of chrysanthemums. Sci. Horti., 63: 457-461.

Hakuzan, R. and Nagayoshi, S. (2013). Effect of night-break light quality on floral inhibition of chrysanthemum. Hortic. Res., 12: 173-178.

Hanke, H. (1996). Short day decreases the risk of later flowering of chrysanthemums. Taspo Gartenbaumagazin, 5 (8): $8-10$

Hayashi, T., Heins, R.D., Cameron, A.C and Carlson, W.H. (2001). Ethephon influences flowering, height, and branching of several herbaceous perennials. Sci. Horti. 91 (3-4): 305-324.

Hong, S.C., Kwon, S.I., Kim, M.K., Chae, M.J., Jung, G.B. and So, K.H. (2013). Flowering Control by Using Red Light of Chrysanthemum. Korean J. Env. Agric., 32 (2): 123-127.

Jaime, A. and Silva, T. (2003). Chrysanthemum: advances in tissue culture, cryopreservation, postharvest technology, genetics and transgenic biotechnology. Biotech. Adv., 21: 715-766

Kahar, S. Ab. (2008). Effects of photoperiod on growth and flowering of Chrysanthemum morifolium Ramat cv. Reagan Sunny. J. Tropical Agric. and Food Sci., 36 (2): 1-8.

Karlovic, K., Vrsek, I., Sindrak, Z. and Zidovec, V. (2004). Influence of growth regulators on the height and number of inflorescence shoots in the Chrysanthemum cultivar 'Revert'. Agric. Conspectus Sci., 69 (2-3): 63-66.

Kaur, P. (2014). Regulation of flower production and post harvest keeping quality in chrysanthemum (Chrysanthemum morifolium Ramat). Ph.D. Dissertation. Punjab Agricultural University, LudhianaIndia.

Kazaz, S., Askin, M.A., Kilic, S. and Ersoy, N. (2010). Effects of day length and daminozide on the flowering, some quality parameters and chlorophyll content of Chrysanthemum morifolium Ramat. Sci. Res. and Essays, 5 (21): 3281-3288.

Korkut, A. (1990). Study on some chrysanthemum cultivars under the unheated glass greenhouse. 5th Greenhouse Symp. 331-339.

Korfranek, A.M. and Halevy, A.H. (1972) .Conditions for opening cut chrysanthemum flower buds. J. American Soc. Horti. Sci., 97: 578- 584.

Kurilcik, A., Dapkuniene, S., Kurilcik, G., Žilinskaite, S., Žukauskas, A. and Duchovskis, P. (2008). Effect of the photoperiod duration on the growth of Chrysanthemum plantlets in vitro. Scientific work of the Lithunian Institute of Horticulture and Lithunian Institute of Agriculture. Sodininkyste Ir Daržininkyste, 27 (2): 39-46.

Larson, A.R. (1992). Introduction to Floriculture. U.K. publishers.

Liao, Y., Suzuki, K., Yu, Y., Zhuang, D., Takai, Y., Ogasawara, R., Shimazu, T and Fukui, H. (2014). Night break effect of LED light with different wavelengths on floral bud differentiation of Chrysanthemum morifolium Ramat "Jimba" and "Iwa no hakusen." Environ. Control Biol., 52: 45-50.

Mattson, N.S. and Erwin, J.E. (2005). The impact of photoperiod and irradiance on flowering of several herbaceous ornamentals. Sci. Horti., 104: 275-292.

Ochiai, M., Liao, Y., Shimazu, T., Takai, Y., Suzuki, K., Yano, S. and Fukui, H. (2015). Varietal differences in flowering and plant growth under night-break treatment with LEDs in 12 chrysanthemum cultivars. Env. Control Bio., 53 (1): 17-22.

Post, K. (1931). Reducing the day length of chrysanthemums for the production of early blooms by the use of black sateen cloth. Proceed. American Soc. Horti. Sci., 28: 382-388.

Runkle, E. and Fisher, P. (2004). Photoperiod and flowering. In: Fisher PR, Runkle E. (eds.), Lighting Up Profits: Understanding Greenhouse Lighting. Meister Media Worldwide, Willoughby, OH, pp. 25-32.

Yamada, A., Tanigawa, T., Suyama, T., Matsuno, T. and Kunitake, T. (2008). Night break treatment using different light source promotes or delay growth and flowering of Eustoma grandiflorum (Raf.) Shinn J. Japan Soc. Horti. Sci., 77: 69-74. 